Article

\title{
Survey of Oomycetes Associated with Root and Crown Rot of Almond in Spain and Pathogenicity of Phytophthora niederhauserii and Phytopythium vexans to 'Garnem' Rootstock
}

\author{
Francisco Beluzán ${ }^{1}$ (D) Xavier Miarnau ${ }^{2}$ D, Laura Torguet ${ }^{2}$, Josep Armengol ${ }^{1}$ (D) and Paloma Abad-Campos ${ }^{1, *}$ \\ 1 Instituto Agroforestal Mediterráneo, Universitat Politècnica de València, Camino de Vera $\mathrm{S} / \mathrm{N}$, \\ 46022 Valencia, Spain; frabeflo@alumni.upv.es (F.B.); jarmengo@eaf.upv.es (J.A.) \\ 2 Fruitcentre, Fruit Production Program, Institut de Recerca i Tecnologia Agroalimentàries (IRTA), PCiTAL, \\ Parc de Gardeny, 25003 Lleida, Spain; xavier.miarnau@irta.cat (X.M.); laura.torguet@irta.cat (L.T.) \\ * Correspondence: pabadcam@eaf.upv.es; Tel.: +34-96-387-9256
}

check for updates

Citation: Beluzán, F.; Miarnau, X.; Torguet, L.; Armengol, J.; Abad-Campos, P. Survey of Oomycetes Associated with Root and Crown Rot of Almond in Spain and Pathogenicity of Phytophthora niederhauserii and Phytopythium vexans to 'Garnem' Rootstock. Agriculture 2022, 12, 294. https:// doi.org/10.3390/agriculture12020294

Academic Editors: Alessandro Vitale, Rosario Paolo Mauro and Ivana Castello

Received: 26 January 2022 Accepted: 17 February 2022 Published: 18 February 2022

Publisher's Note: MDPI stays neutral with regard to jurisdictional claims in published maps and institutional affiliations.

Copyright: (c) 2022 by the authors. Licensee MDPI, Basel, Switzerland. This article is an open access article distributed under the terms and conditions of the Creative Commons Attribution (CC BY) license (https:// creativecommons.org/licenses/by/ $4.0 /)$.

\begin{abstract}
From 2018 to 2020, surveys of oomycetes associated with root and crown rot of almond (Prunus dulcis) were conducted on diseased young almond trees in commercial orchards and nurseries in six provinces of Spain. A total of 104 oomycete isolates were obtained from plant and soil samples, which $\mathrm{h}$ were identified by sequencing the internal transcribed spacer (ITS) region of the ribosomal DNA. Diverse species belonging to the genera Globisporangium, Phytophthora, Phytopythium and Pythium were found, Phytopythium vexans and Phytophthora niederhauserii being the most frequent. The pathogenicity of these two species to one-year-old almond seedlings of 'Garnem' (P. dulcis $\times$ P. persica) rootstock was studied. All seedlings inoculated with $P p$. vexans and $P h$. niederhauserii isolates showed severe symptoms at the late stage of the pathogenicity test (defoliation, wilting and dieback) and several plants died. Some isolates of Ph. niederhauserii significantly reduced the dry weight of the roots compared with the control, but this effect was not observed in seedlings inoculated with $P p$. vexans. These results provide new information about the oomycete species present in almond crops in Spain and highlight the importance of carrying out frequent phytosanitary surveys for a better knowledge of potential risks posed by these soil-borne pathogens.
\end{abstract}

Keywords: nut crops; PCR; plant-pathogen interactions; Prunus; soil-borne pathogens

\section{Introduction}

In the Mediterranean area, almond crops (Prunus dulcis (Miller) D.A. Webb. syn. Prunus amygdalus Batsch) are cultivated mainly in marginal soils and rainfed conditions, quite the opposite to what happens in the USA and Australia, the two major almond producers [1], where almond crop is grown under irrigation conditions. Specifically, in Spain, this crop has been traditionally planted throughout the Mediterranean coastline, where lighter and poor soils are found and it has been cultivated mainly in dry conditions [2]. It was not until about the 2000s that almond crops began to be planted in irrigated lands in new Spanish cropping areas, with heavier and clayey soils, until then used to grow other fruit trees or extensive crops [3].

In this new Spanish almond crop paradigm, some already known diseases and new ones have emerged, mainly soil-borne diseases [4]. The incorporation of irrigation systems together with the exploration of diverse soil types (previously destined for other uses) has increased the root system problems related to waterlogging cases associated with root asphyxia and the proliferation of certain root and crown diseases. In addition, the 'GF-677' and 'Garnem' rootstocks, both hybrids of $P$. dulcis $\times$ P. persica, used massively up to now in almond crops mainly in irrigated orchards but also in dry crop conditions, are susceptible to soil-borne diseases [5]. New hybrid rootstocks obtained from crosses of almond or peach with plum species have appeared in recent years to avoid these problems [5-7]. These new 
materials have certain tolerance or resistance to soil-borne diseases, but it is important to note that the area planted with them is still reduced.

Almond trees can be affected by several soil-borne pathogens, such as Armillaria mellea (Vahl: Fr.) P. Kumm., Rosellinia necatrix Prill. and some oomycetes [8]. Diseases caused by oomycetes present in the soil can affect the crown and the roots of almond trees in both the nursery and established orchards. Multiple routes can spread out these diseases from the nurseries with infected plant material and infested substrate. Once established in the orchard, they can spread rapidly through cultural practices, plant debris, or through irrigation water [9]. Plant pathogenic oomycetes have evolved large arsenals of secreted proteins, termed effectors, that act as weapons in order to successfully infect plants, which respond by multiple defense actions, including the strengthening of physical barriers, production of antimicrobial molecules and programmed cell death. Oomycetes can counteract the plant's immunity mechanisms, interfering or suppressing numerous biochemical signaling components, disabling the host's defense actions, thus managing to invade its tissues [10].

Pinto de Torres and Mircetich [11] reported, in Chile, the presence of cankers caused by Globisporangium ultimum at the base of the trunk in 2-year-old almond trees. In Iran, Azizi et al. [12] studied the pathogenicity towards almonds of Pythium (Py.) (sensu lato) and Phytophthora $(P h$.$) isolates obtained from soil and roots of young almond trees. These$ authors identified Ph. cactorum, Py. aphanidermatum and Phytopythium (Pp.) helicoides as pathogenic species for this host, causing death in almond seedlings. Later, in this same country, Javadi and Sharifnabi [13] reported Pp. litorale as the pathogen causing root and crown rot of almond trees. This information was confirmed by Browne et al. [14], who indicated that diverse Pythium and Phytopythium species have been associated with the suppression of growth in the replanting of Prunus orchards grafted onto 'Nemaguard' rootstock, but their pathogenicity to almond or peach rootstocks was only established for G. ultimum var. ultimum and G. irregulare.

Many authors have reported diverse species of the genus Phytophthora causing root infection on almond rootstocks. Browne et al. [15] indicated that more than 10 species of Phytophthora attack almond trees, causing root rot and cankers on the root crown, trunk, or scaffolds. Earlier works by Wicks and Lee [16] and Wicks [17] in Australia reported the isolation of Ph. cambivora, Ph. citrophthora, Ph. cryptogea and Ph. megasperma from either crown cankers or the soil around the crown of declining almond trees. These authors were only able to test the pathogenicity of Ph. cambivora in almond seedlings grown in artificially infested soil. Later, Browne and Viveros [18] reported Ph. megasperma, Ph. cactorum and Ph. citricola associated with crown rot on dying almond trees in California, which were often of nonbearing age. Subsequent studies in Iran confirmed the pathogenicity of Ph. cactorum in a local almond rootstock [19]. In Spain, a new Phytophthora sp. associated with 2-year-old almond plants was detected in a Valencian nursery in 2007. Symptoms associated with this pathogen were chlorosis, wilting, cankers and profuse stem gumming [20]. From the infected plant material, it was possible to isolate Phytophthora taxon niederhauserii, which was confirmed as the causal agent of the disease by means of a pathogenicity test. Later, Kurbetli and Değirmenci [21] detected this pathogen for the first time, in almond orchards in Turkey. The description of this new species was completed by Abad et al. [22], who established Ph. niederhauserii as its definitive name. This oomycete is capable of infecting at least 33 species from 25 different families in both agricultural ecosystems and ornamental plant nurseries [22]. Later, in 2015, Ph. niederhauserii was first detected, causing almond crown rot in California [15]. Finally, more recent publications have reported symptoms of cankers and root and crown rot in almond trees, associated with Ph. megasperma [23] and Ph. plurivora [24] in Turkey; and wilting and decreased vigor caused by Ph. chlamydospora in Turkey [25] and California [26].

There is a lack of updated information about the diversity of oomycetes infecting almond trees in Spain. Thus, the objectives of this study are: (i) to survey, isolate and identify oomycetes from almond trees showing root and crown rot symptoms in the main 
producing areas of Spain; and (ii) to study the pathogenicity to 'Garnem' rootstock of the most frequent species found.

\section{Materials and Methods}

\subsection{Field and Nursery Survey and Sampling}

From 2018 to 2020, diseased young almond trees, of 1-3 years old, showing the symptoms root necrosis and root rot, cankers at the crown area, gum exudates at the base of the trunk and general decline (leaf yellowing, defoliation and wilting) (Figure 1), were surveyed in commercial orchards and nursery fields in Spain. The sampling sites were selected in order to represent the main almond-growing regions and different environmental conditions. A total of 149 samples was collected in six provinces, Córdoba (4 samples), Huelva $(n=5)$, Lleida $(n=39)$, Sevilla $(n=9)$, Toledo $(n=10)$ and Valencia $(n=82)$ (Figure 2$)$. Each sample was composed of the base of the trunk of the symptomatic tree, the entire root system and from 2 to $4 \mathrm{~kg}$ of adjacent soil.
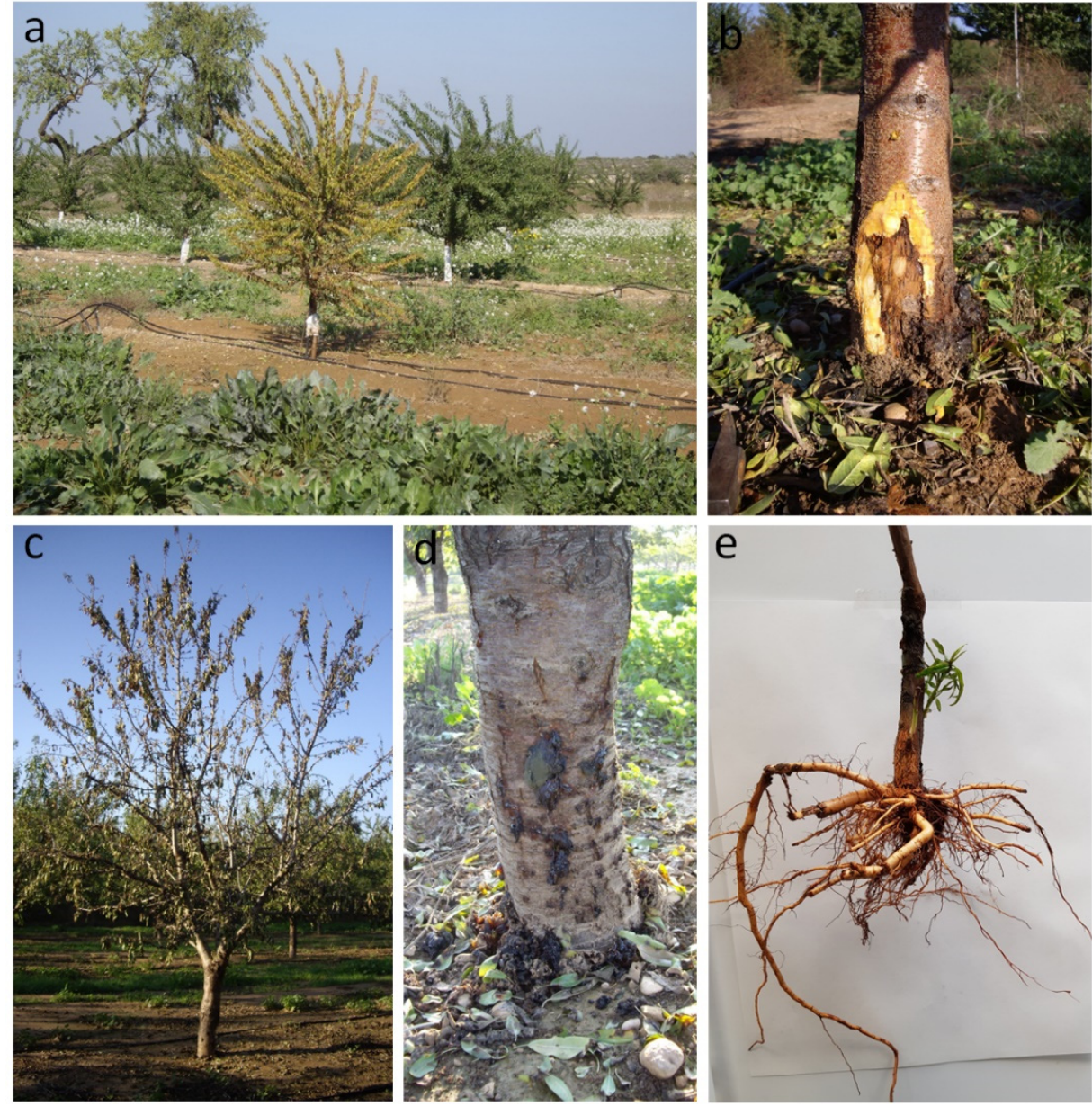

Figure 1. Symptoms observed in field and nursery samples of almond trees: (a) leaf yellowing; (b) canker and crown rot; (c) general decline; (d) gum exudates at the base of the trunk; (e) root and crown rot. 


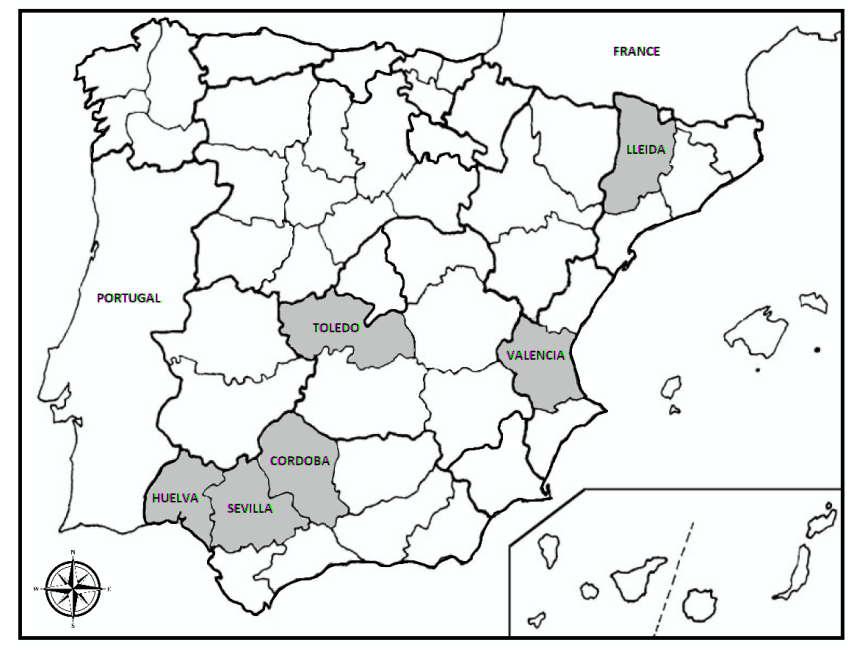

Figure 2. Map showing the location of sampled provinces in Spain. The sampled provinces are highlighted in light gray.

\subsection{Isolation of Oomycetes from Plant and Soil Samples}

Samples were brought to the laboratory for analysis. The crown area and the roots were carefully washed under running tap water to rinse the oil away. Segments from the crown and primary and secondary roots showing symptoms of browning and necrosis were cut. These plant tissue fragments were disinfected with $70 \%$ ethanol for $30 \mathrm{~s}$, then rinsed with sterile distilled water and allowed to dry on absorbent paper. Pieces from 1 to $2 \mathrm{~mm}$ long were cut in a laminar flow chamber and seeded in Petri dishes with Corn Meal Agar with Pimaricin + Ampicillin + Rifampicin + Pentachloronitrobenzene + Benomyl (CMA-PARPB) medium and CMA-PARPBH (CMA-PARPB corrected with 0,069 g/L of Hymexazol) and then incubated at $25^{\circ} \mathrm{C}$ for $72 \mathrm{~h}$ [27]. Pure cultures were obtained by transferring the mycelial growth of the margins of colonies to potato dextrose agar medium (PDA; Biokar-Diagnostics, Beauvais, France) for their subsequent identification [28].

For the isolation of oomycetes from the soil, two trapping modalities were applied. For the first, the soil was placed in $10 \times 30 \times 10 \mathrm{~cm}$ plastic buckets, then moistened and saturated with distilled water. Hedera helix L., Robinia pseudoacacia L. and Pittosporum tobira (Thunb.) W.T.Aiton young leaves were added to the surface of the water and incubated in a growth chamber at $23{ }^{\circ} \mathrm{C}$ for 3-7 days until points of infection appeared [29]. For the second, Granny Smith apples were used as baits. Four perpendicular perforations of $1 \mathrm{~cm}^{2}$ in diameter were made around an apple previously disinfected with $96 \%$ alcohol. In each perforation, a previously moistened soil subsample was added and covered with a plastic tape, to maintain humidity. The apples were incubated at room temperature for 3-7 days [28]. The leaves and apples that presented necrotic or watery lesions were cut into 1-2 mm pieces and seeded in Petri dishes with CMA-PARPB and CMA-PARPBH media, then incubated at $25^{\circ} \mathrm{C}$ for one week, checking daily for the development of oomycete-like colonies. Pure cultures were transferred to PDA as described above. The oomycete isolates were stored in an incubator at $10{ }^{\circ} \mathrm{C}$, in plates with oatmeal agar, in the dark, at Instituto Agroforestal Mediterráneo in Universitat Politècnica de València (IAM-UPV; Valencia, Spain).

\subsection{DNA Isolation, Amplification and Sequencing of Oomycetes}

Genomic DNA was obtained from a one-week-old pure culture of each sample to be analyzed, grown on PDA at $25^{\circ} \mathrm{C}$ in the dark. For DNA extraction, the method of Collado-Romero et al. [30] was used, with a slight variation, whereby the mycelium was scraped with a sterile pipette tip and placed in a $0.2 \mathrm{~mL}$ polymerase chain reaction (PCR) tube with $20 \mu \mathrm{L}$ of $25 \mathrm{mM} \mathrm{NaOH}$ at pH 12. The tubes with the samples were incubated in a PTC 200 thermal cycler (MJ Research Inc., Waltham, MA, USA) with a DNA denaturation program $\left(100{ }^{\circ} \mathrm{C}\right.$ for $15 \mathrm{~min}$ and $4{ }^{\circ} \mathrm{C}$ for $\left.5 \mathrm{~min}\right)$. Subsequently, $40 \mu \mathrm{L}$ of $40 \mathrm{mM}$ Tris- $\mathrm{HCl}$ 
was added at $\mathrm{pH} 5$. The ITS region of the ribosomal DNA of the isolates was amplified, using universal primers ITS-6 (5' GAA GGT GAA GTC GTA ACA AGG 3') [31] and ITS-4 (5' TCC TCC GCT TAT TGA TATGC 3') [32]. Each PCR tube contained water $(13.3 \mu \mathrm{L})$, Canvax Buffer B (x) $(2.5 \mu \mathrm{L})$, Canvax $\mathrm{MgCl}_{2}(\mathrm{nM})(2.5 \mu \mathrm{L})$, Canvax dNTPs $(\mathrm{nM})(2.5 \mu \mathrm{L})$, Canvax Horse Power Taq polymerase $(\mathrm{U} / \mu \mathrm{L})(0.2 \mu \mathrm{L})$, primers $(1 \mu \mathrm{L}$ of each) and genomic DNA $(2 \mu \mathrm{L})$, for a total of $25 \mu \mathrm{L}$. PCR amplification was performed in the same thermocycler mentioned above, using the following program: initial denaturation of 1 cycle at $94{ }^{\circ} \mathrm{C}$ for $3 \mathrm{~min} ; 35$ cycles of denaturation, annealing and extension at $94{ }^{\circ} \mathrm{C}$ for $30 \mathrm{~s}, 55^{\circ} \mathrm{C}$ for $30 \mathrm{~s}$ and $72{ }^{\circ} \mathrm{C}$ for $45 \mathrm{~s}$, respectively; and a final amplification cycle at $72{ }^{\circ} \mathrm{C}$ for $10 \mathrm{~min}$. The PCR products were electrophoresed $(140 \mathrm{~V})$ on $1.5 \%$ agarose gel $(1.5 \%$ agarose dissolved in TAE buffer (Tris-acetate-EDTA) $40 \mathrm{mM}$ Tris-acetate, $1 \mathrm{mM}$ EDTA) 1X; the staining of nucleic acids was made with RedSafe $(20,000 \times)$. To identify the size of the bands, a molecular marker (GeneRuler T.M. 100 bp Plus DNA Ladder; Thermo Scientific, Waltham, MA, USA) was loaded into the first well of the gel. The presence of the bands was observed with the aid of a UV light transilluminator. The PCR products were sent to Macrogen (Madrid, Spain) for sequencing. The sequences obtained were subjected to a search in NCBI BLAST (http: / / blast.ncbi.nlm.nih.gov/Blast.cgi; accessed on 15 October 2021), identifying the isolates at the species level.

\subsection{Pathogenicity Tests}

The inoculum was prepared in $1 \mathrm{~L}$ glass flasks with a mix of $200 \mathrm{~mL}$ of vermiculite, $20 \mathrm{~mL}$ of oat grains and $175 \mathrm{~mL}$ of eight vegetables (V8) broth (200 mL/L of V8 juice, $800 \mathrm{~mL} / \mathrm{L}$ of demineralized water and $2 \mathrm{~g} / \mathrm{L}$ of $\mathrm{CaCO}_{3}$ ) [33]. The glass flasks were sterilized three times for $20 \mathrm{~min}$ at $120^{\circ} \mathrm{C}$ in an autoclave.

The flasks were inoculated separately with four isolates of $\mathrm{Ph}$. niederhauserii (PAL-21, PAL-62, PAL74 and PAL-100) and one isolate of Pp. vexans (PAL-98), previously grown on V8 media (V8A). Inoculated flaks were incubated for six weeks in the dark at room temperature [34]. After this time, the inoculum mixture was rinsed with demineralized water to remove excess nutrients, before inoculations.

The pathogenicity tests were conducted on one-year-old almond seedlings of 'Garnem' rootstock. Seedlings were selected based on morphological homogeneity and healthy appearance. For inoculation, $20 \mathrm{~g}$ of inoculum was added to plastic pots with $200 \mathrm{~g}$ of potting mix that contained peat, vermiculite and sand $(1: 1: 1, \mathrm{v} / \mathrm{v} / \mathrm{v})$, autoclaved three times prior to use; then, the rootstocks were planted. Control plants were inoculated with a non-infested inoculum mixture. In total, 5 plants were inoculated for each isolate and control and the experiment was repeated. All plants were randomly distributed in a growth chamber under a $12 \mathrm{~h}$ photoperiod at $23^{\circ} \mathrm{C}$. All seedlings were watered the day before the inoculation. Immediately after inoculation, the seedlings were flooded for $48 \mathrm{~h}$ and the flooding was repeated every two weeks to stimulate the formation of zoosporangia, as previously described by Pérez-Sierra et al. [34].

The experiment was completed 58 days after inoculation. Seedlings were uprooted and the root system was washed carefully under running water to remove the substrate. Re-isolations from seedlings were performed by plating symptomatic fine root fragments in CMA-PARPBH to confirm Koch's postulates.

Severity evaluations for each plant started ten days after inoculation; then, they were performed every four days until the end of the experiment. Severity was evaluated using the following scale: $0=$ symptom-free plant; $1=$ foliar chlorosis; $2=$ wilting, dieback and defoliation; and 3 = dead plant [35]. With the severity values of each plant over time, the area under the disease-progress curve (AUDPC) was calculated by the trapezoidal integration method [36].

The dry weight of the root biomass was measured. For this purpose, roots were separated from the main stem and shoots by cutting at the root crown, then placed into paper bags and dried for five days in an oven at $35^{\circ} \mathrm{C}$. The dry weight of the roots was recorded. 


\subsection{Data Analysis}

An analysis of variance (ANOVA) was performed for the dry weight of the root biomass and AUDPC. The assumptions of normality and homoscedasticity of the ANOVA were previously verified. Those data that did not meet the assumptions were transformed to the reciprocal value $(1 / \times)$. Mean values were compared using the least significant difference (LSD) test at the $99 \%$ confidence level. All calculations were performed using Statgraphics Centurion XVI (Statgraphics Technologies, Inc., The Plains, VA, USA).

\section{Results}

\subsection{Occurrence of Oomycetes in Almond Samples}

A total of 104 oomycete isolates was obtained (Table 1). Lleida was the province in which the most isolates were obtained, 41 , representing $39.4 \%$ of the total, followed by Valencia, with 29 (27.8\%). Fewer isolates were obtained from the Huelva, Toledo, Sevilla and Córdoba provinces, having 12 (11.5\%), 11 (10.5\%), 7 (6.7\%) and 4 (3.8\%), respectively.

Table 1. Origin and GenBank accession numbers of Globisporangium, Phytophthora, Phytopythium and Pythium species recovered from almond tree samples showing root and crown rot symptoms in six provinces of Spain.

\begin{tabular}{|c|c|c|c|c|c|}
\hline Species & Code & Geographic Origin & Source & Rootstock/Scion & Acc. No. \\
\hline Globisporangium carolinianum & PAL-106 & Valencia & Soil & & MZ921970 \\
\hline G. carolinianum & PAL-13 & Lleida & Soil & & MZ921972 \\
\hline G. carolinianum & PAL-69 & Valencia & Soil & & MZ922023 \\
\hline G. echinulatum & PAL-44 & Toledo & Soil & & MZ921949 \\
\hline G. glomeratum & PAL-107 & Valencia & Soil & & MZ921971 \\
\hline G. glomeratum & PAL-14 & Lleida & Soil & & MZ921973 \\
\hline G. glomeratum & PAL-41 & Lleida & Soil & & MZ922001 \\
\hline G. heterothallicum & PAL-42 & Toledo & Soil & & MZ922002 \\
\hline G. hypogynum & PAL-68 & Valencia & Soil & & MZ921955 \\
\hline G. irregulare & PAL-45 & Toledo & Soil & & MZ922003 \\
\hline G. irregulare & PAL-46 & Toledo & Soil & & MZ922004 \\
\hline G. irregulare & PAL-47 & Toledo & Soil & & MZ922005 \\
\hline G. irregulare & PAL-48 & Toledo & Soil & & MZ922006 \\
\hline G. irregulare & PAL-49 & Toledo & Soil & & MZ922007 \\
\hline G. irregulare & PAL-51 & Toledo & Soil & & MZ922009 \\
\hline G. irregulare & PAL-52 & Toledo & Soil & & MZ922010 \\
\hline G. irregulare & PAL-90 & Huelva & Soil & & MZ922042 \\
\hline G. irregulare & PAL-91 & Sevilla & Root & 'Rootpac-40' / nd & MZ922043 \\
\hline G. middletonii & PAL-15 & Lleida & Soil & & MZ921965 \\
\hline G. speculum & PAL-50 & Toledo & Soil & & MZ921950 \\
\hline G. ultimum var. ultimum & PAL-17 & Lleida & Soil & & MZ921974 \\
\hline G. ultimum var. ultimum & PAL-58 & Valencia & Root & 'GF-677' /'Lauranne' & MZ922015 \\
\hline G. ultimum var. ultimum & PAL-61 & Valencia & Root & ‘GF-677' / 'Lauranne' & MZ922017 \\
\hline G. ultimum var. ultimum & PAL-63 & Valencia & Soil & & MZ922018 \\
\hline G. ultimum var. ultimum & PAL-79 & Huelva & Soil & & MZ922030 \\
\hline G. ultimum var. ultimum & PAL-84 & Huelva & Soil & & MZ922035 \\
\hline G. ultimum var. ultimum & PAL-92 & Sevilla & Soil & & MZ922044 \\
\hline G. ultimum var. ultimum & PAL-94 & Sevilla & Soil & & MZ922046 \\
\hline Phytophthora cactorum & PAL-10 & Lleida & Soil & & MZ921975 \\
\hline Ph. cactorum & PAL-12 & Lleida & Soil & & MZ921977 \\
\hline Ph. cactorum & PAL-24 & Lleida & Soil & & MZ921983 \\
\hline Ph. cactorum & PAL-28 & Lleida & Soil & & MZ921984 \\
\hline Ph. cactorum & PAL-35 & Lleida & Soil & & MZ921994 \\
\hline Ph. cactorum & PAL-38 & Lleida & Soil & & MZ921997 \\
\hline Ph. cactorum & PAL-4 & Lleida & Soil & & MZ921999 \\
\hline
\end{tabular}


Table 1. Cont.

\begin{tabular}{|c|c|c|c|c|c|}
\hline Species & Code & Geographic Origin & Source & Rootstock/Scion & Acc. No. \\
\hline Ph. citrophthora & PAL-16 & Lleida & Soil & & MZ921978 \\
\hline Ph. citrophthora & PAL-18 & Lleida & Soil & & MZ921979 \\
\hline Ph. citrophthora & PAL-19 & Lleida & Soil & & MZ921980 \\
\hline Ph. citrophthora & PAL-2 & Lleida & Soil & & MZ921981 \\
\hline Ph. citrophthora & PAL-20 & Lleida & Soil & & MZ921982 \\
\hline Ph. humicola/condilina & PAL-5 & Lleida & Soil & & MZ922008 \\
\hline Ph. nicotianae & PAL-57 & Valencia & Soil & & MZ922014 \\
\hline Ph. nicotianae & PAL-71 & Valencia & Soil & & MZ922025 \\
\hline Ph. niederhauserii & PAL-11 & Lleida & Soil & & MZ921964 \\
\hline Ph. niederhauserii & PAL-34 & Lleida & Soil & & MZ921969 \\
\hline Ph. niederhauserii & PAL-60 & Valencia & Root & 'GF-677' /'Lauranne' & MZ921953 \\
\hline Ph. niederhauserii & PAL-62 & Valencia & Root & 'GF-677' /'Lauranne' & MZ921954 \\
\hline Ph. niederhauserii & PAL-1 & Lleida & Soil & & MZ921961 \\
\hline Ph. niederhauserii & PAL-100 & Córdoba & Root & ‘GF-677’ /nd & MZ921962 \\
\hline Ph. niederhauserii & PAL-105 & Valencia & Root & 'Garnem/'Lauranne' & MZ921963 \\
\hline Ph. niederhauserii & PAL-21 & Lleida & Soil & & MZ921966 \\
\hline Ph. niederhauserii & PAL-26 & Lleida & Soil & & MZ921967 \\
\hline Ph. niederhauserii & PAL-3 & Lleida & Soil & & MZ921968 \\
\hline Ph. niederhauserii & PAL-6 & Lleida & Soil & & MZ921952 \\
\hline Ph. niederhauserii & PAL-7 & Lleida & Soil & & MZ921956 \\
\hline Ph. niederhauserii & PAL-74 & Valencia & Soil & & MZ921957 \\
\hline Ph. niederhauserii & PAL-77 & Valencia & Soil & & MZ921958 \\
\hline Ph. niederhauserii & PAL-78 & Valencia & Root & 'GF-677' / nd & MZ921959 \\
\hline Ph. niederhauserii & PAL-8 & Lleida & Soil & & MZ921960 \\
\hline Ph. palmivora & PAL-66 & Valencia & Soil & & MZ922021 \\
\hline Ph. palmivora & PAL-72 & Valencia & Soil & & MZ922026 \\
\hline Ph. tropicalis & PAL-101 & Córdoba & Soil & & MZ921976 \\
\hline Phytopythium chamaehyphon & PAL-99 & Córdoba & Soil & & MZ922051 \\
\hline Pp. cucurbitacearum & PAL-53 & Valencia & Root & 'Garnem' / nd & MZ921951 \\
\hline Pp. helicoides & PAL-76 & Valencia & Root & 'Garnem'/'Penta' & MZ922029 \\
\hline Pp. helicoides & PAL-96 & Sevilla & Root & 'GF-677' / nd & MZ922048 \\
\hline Pp. mercuriale & PAL-86 & Huelva & Soil & & MZ922037 \\
\hline Pp. mercuriale & PAL-87 & Huelva & Soil & & MZ922038 \\
\hline Pp. vexans & PAL-22 & Lleida & Soil & & MZ921985 \\
\hline Pp. vexans & PAL-23 & Lleida & Root & ‘GF-677' /'Constantí' & MZ921986 \\
\hline Pp. vexans & PAL-25 & Lleida & Root & 'GF-677' /’Vairo' & MZ921987 \\
\hline Pp. vexans & PAL-27 & Lleida & Root & ‘GF-677' /'Marinada' & MZ921988 \\
\hline Pp. vexans & PAL-29 & Lleida & Root & 'Garnem' /'Soleta' & MZ921989 \\
\hline Pp. vexans & PAL-32 & Lleida & Soil & & MZ921992 \\
\hline Pp. vexans & PAL-33 & Lleida & Soil & & MZ921993 \\
\hline Pp. vexans & PAL-36 & Lleida & Soil & & MZ921995 \\
\hline Pp. vexans & PAL-37 & Lleida & Soil & & MZ921996 \\
\hline Pp. vexans & PAL-40 & Lleida & Soil & & MZ922000 \\
\hline Pp. vexans & PAL-59 & Valencia & Root & 'GF-677' /'Lauranne' & MZ922016 \\
\hline Pp. vexans & PAL-70 & Valencia & Soil & & MZ922024 \\
\hline Pp. vexans & PAL-73 & Valencia & Soil & & MZ922027 \\
\hline Pp. vexans & PAL-75 & Valencia & Soil & & MZ922028 \\
\hline Pp. vexans & PAL-82 & Huelva & Soil & & MZ922033 \\
\hline Pp. vexans & PAL-83 & Huelva & Soil & & MZ922034 \\
\hline Pp. vexans & PAL-85 & Huelva & Soil & & MZ922036 \\
\hline Pp. vexans & PAL-88 & Huelva & Soil & & MZ922039 \\
\hline Pp. vexans & PAL-89 & Huelva & Soil & & MZ922040 \\
\hline Pp. vexans & PAL-9 & Lleida & Soil & & MZ922041 \\
\hline Pp. vexans & PAL-93 & Sevilla & Soil & & MZ922045 \\
\hline Pp. vexans & PAL-98 & Córdoba & Root & 'GF-677' /nd & MZ922050 \\
\hline
\end{tabular}


Table 1. Cont.

\begin{tabular}{|c|c|c|c|c|c|}
\hline Species & Code & Geographic Origin & Source & Rootstock/Scion & Acc. No. \\
\hline Pythium aphanidermatum & PAL-39 & Lleida & Soil & & MZ921998 \\
\hline Py. dissotocum & PAL-30 & Lleida & Soil & & MZ921990 \\
\hline Py. dissotocum & PAL-31 & Lleida & Soil & & MZ921991 \\
\hline Py. dissotocum & PAL-54 & Valencia & Soil & & MZ922011 \\
\hline Py. dissotocum & PAL-55 & Valencia & Soil & & MZ922012 \\
\hline Py. dissotocum & PAL-65 & Valencia & Soil & & MZ922020 \\
\hline Py. dissotocum & PAL-80 & Huelva & Soil & & MZ922031 \\
\hline Py. dissotocum & PAL-81 & Huelva & Soil & & MZ922032 \\
\hline Py. dissotocum & PAL-95 & Sevilla & Soil & & MZ922047 \\
\hline Py. dissotocum & PAL-97 & Sevilla & Soil & & MZ922049 \\
\hline Py. nodosum & PAL-56 & Valencia & Soil & & MZ922013 \\
\hline Py. nodosum & PAL-64 & Valencia & Soil & & MZ922019 \\
\hline Py. nodosum & PAL-67 & Valencia & Soil & & MZ922022 \\
\hline Py. pachycaule & PAL-43 & Toledo & Soil & & MZ921948 \\
\hline
\end{tabular}

Acc. No.: accession number; nd: not determined.

The most frequent genus was Phytophthora, representing 32.7\% of isolates, followed by Globisporangium and Phytopythium both with $26.9 \%$ and Pythium with $13.4 \%$ of the total isolates. Regarding the species frequency (Figure 3), the most frequent was $P p$. vexans, which represented $21.2 \%$ of the isolates, followed by $\mathrm{Ph}$. niederhauserii $(15.4 \%)$. Less frequent species were G. irregulare and Py. dissotocum (8.7\%), G. ultimum var. ultimum (7.7\%), Ph. cactorum (6.7\%) and Ph. citrophthora (4.8\%). The remaining species had percentages below $3 \%$. Regarding the source of isolation, $83.6 \%$ of the oomycetes were isolated from soil samples with baiting techniques and only $16.3 \%$ were isolated directly from the roots.

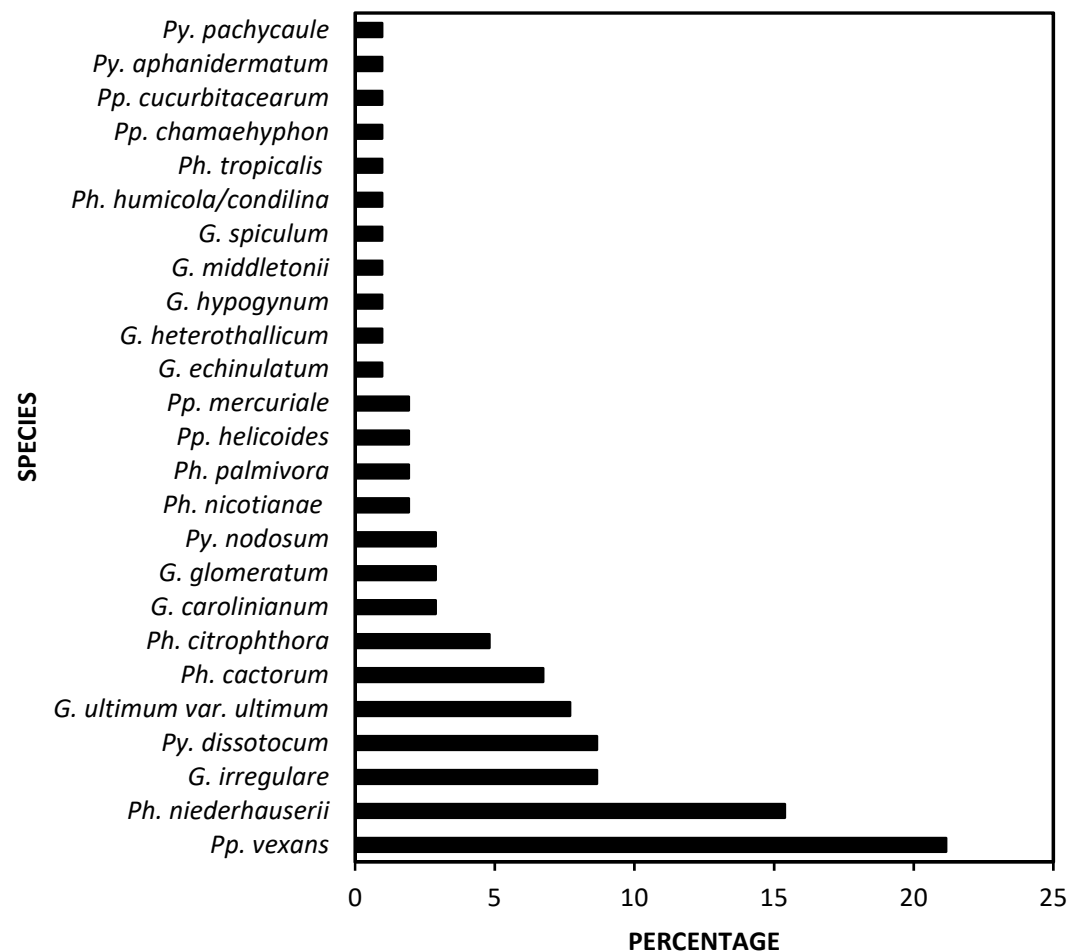

Figure 3. Frequency of occurrence of Globisporangium, Phytophthora, Phytopythium and Pythium species recovered from almond orchards showing root and crown rot symptoms in six provinces of Spain $(n=104)$.

\subsection{Pathogenicity Tests}

All 'Garnem' seedlings inoculated with $P h$. niederhauserii and $P p$. vexans isolates showed root symptoms (small dark necrotic lesions, root cankers, loss of fine roots and 
tap root rot), as well as aerial symptoms (chlorosis, wilting and defoliation), and some plants died. The re-isolations from symptomatic roots confirmed Koch's postulates. In contrast, control treatment seedlings remained healthy and it was not possible to re-isolate $P h$. niederhauserii and $P p$. vexans from the roots.

The severity of the infections and the AUDPC calculated for each isolate of $\mathrm{Ph}$. niederhauserii and $P p$. vexans are shown in Figures 4 and 5. In general, the symptoms appeared earlier in the rootstocks inoculated with the isolate PAL-98 of Pp. vexans (10 days post-inoculation), where the disease progressed rapidly, reaching an AUDPC of 62.8 at day 58 after inoculation. The symptoms caused by isolates PAL-62, PAL-74 and PAL-100 of Ph. niederhauserii started on day 26 after inoculation for the three isolates, reaching an AUDPC value of 53, 64.6 and 62.8 , respectively, at 58 days after inoculation. The latest isolate in the expression of symptoms was PAL-21, which started 30 days after inoculation, reaching a value of 40.4 of AUDPC, this being the lowest value obtained for all the inoculated isolates. The ANOVA analysis showed statistically significant differences in the AUDPC mean values $(P \leq 0.01)$ between the PAL-21 isolate and the other inoculated species. There were no statistically significant differences in the AUDPC of the isolates PAL-62, PAL-74, PAL-98 and PAL-100.

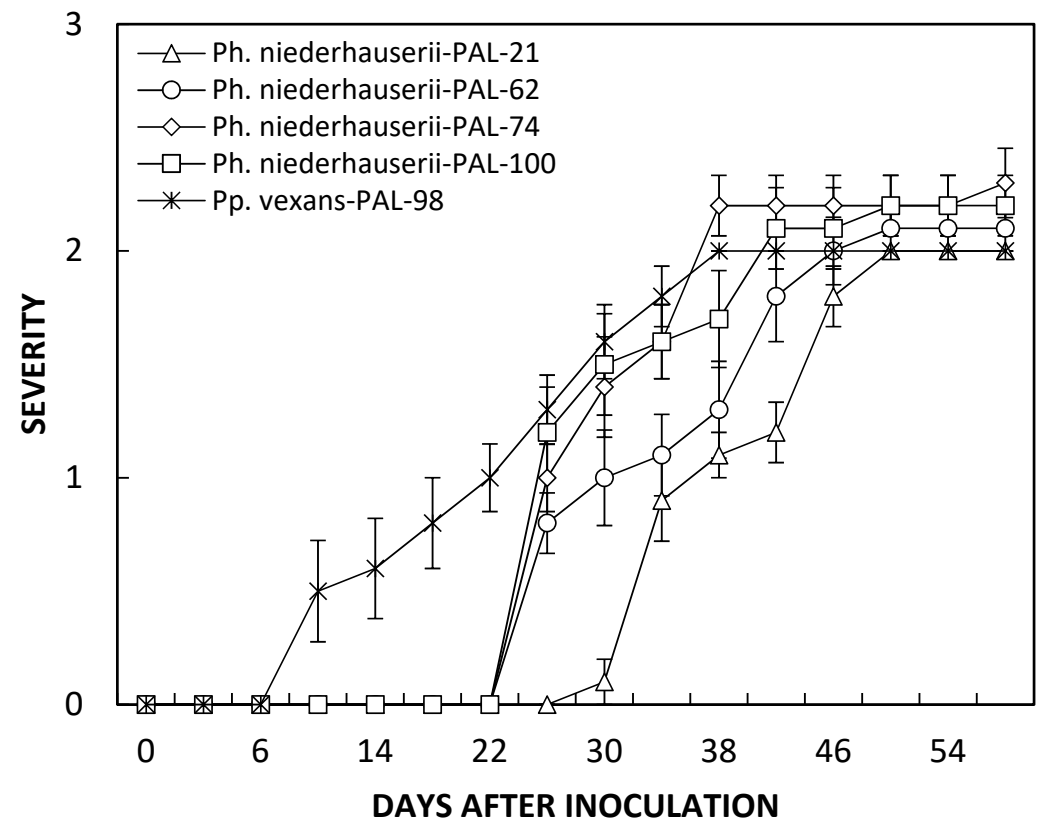

Figure 4. Results of severity of four isolates of Ph. niederhauserii and one of Pp. vexans to 'Garnem' rootstock 58 days after inoculation. Severity was evaluated using the following scale: $0=$ symptomfree plant; 1 = foliar chlorosis; 2 = wilting, dieback and defoliation; and 3 = dead plant. Values are the mean of 10 almond seedlings. The vertical bars represent the standard error of the mean.

The root dry-weight results are shown in Figure 6. There were statistically significant differences $(P \leq 0.01)$ between the root dry weight of the control and the isolates PAL-74 and PAL-100 of Ph. niederhauserii, which caused a 33\% and a 31\% reduction in root dry weight when compared with the un-inoculated control, respectively. There were no statistically significant differences between the control and the isolates PAL-21 and PAL-62 of Ph. niederhauserii and the isolate PAL-98 of Pp. vexans. Although, in the isolates PAL-21 and PAL-62, there were no statistically significant differences with respect to the control, a reduction in the mean weight of $22 \%$ and $18 \%$, respectively, was observed when they were compared with the control. 


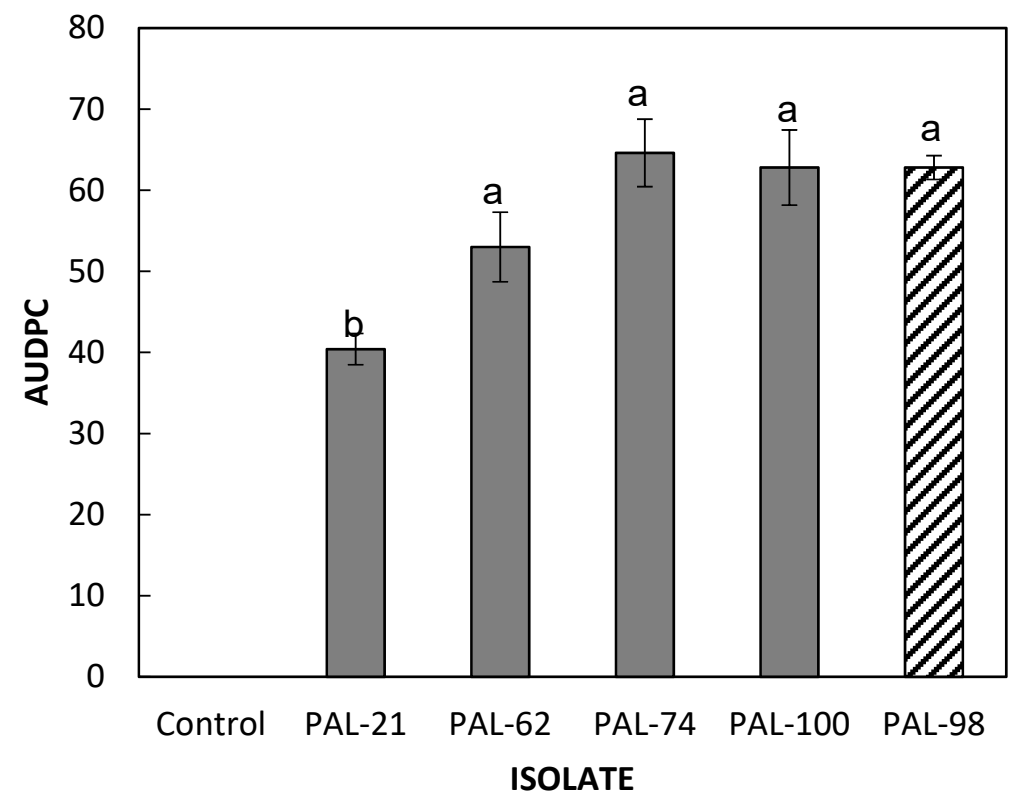

Figure 5. Results of area under the disease progress curve AUDPC of four isolates of Ph. niederhauserii and one of $P p$. vexans to 'Garnem' rootstock 58 days after inoculation. The vertical bars represent the standard error of the mean. The letters indicate significant differences (LSD; $P \leq 0.01$ ) among the means. The white column represents the control, gray columns represent the isolates of $P h$. niederhauserii and the striped column represents the isolate of $P p$. vexans.

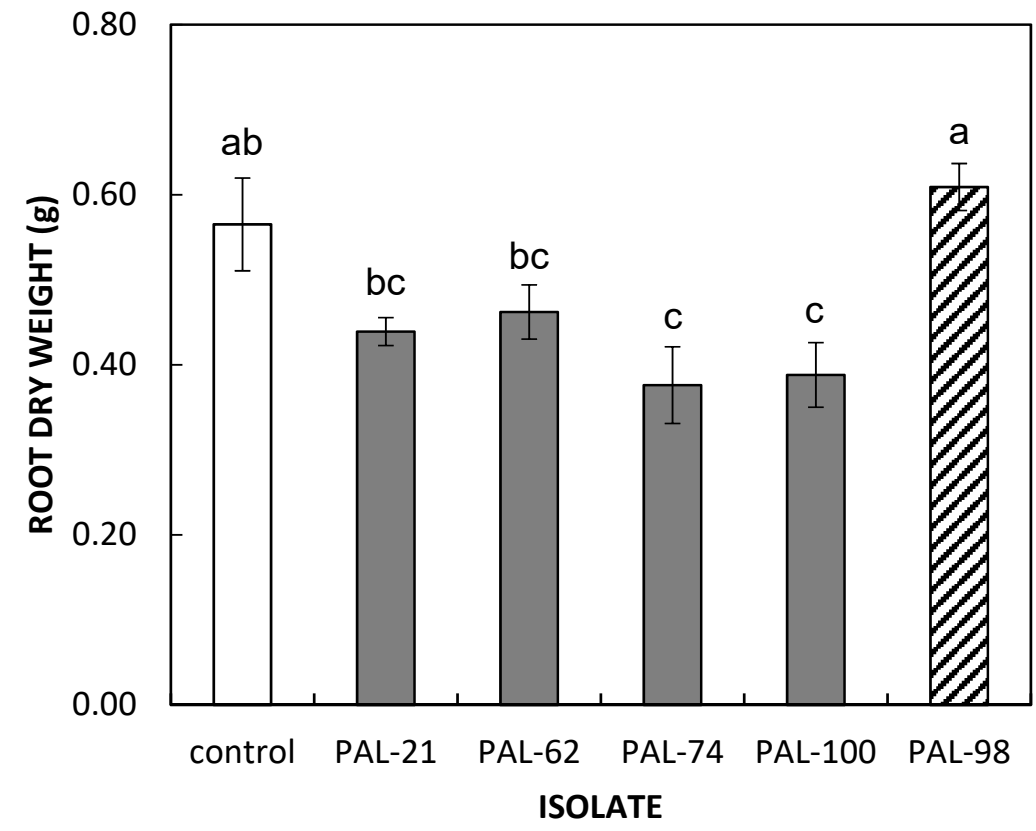

Figure 6. Results of root dry weight of four isolates of Ph. niederhauserii and one of $P p$. vexans to 'Garnem' rootstock 58 days after inoculation. The vertical bars represent the standard error of the mean. The letters indicate significant differences (LSD; $P \leq 0.01$ ) among the isolates' means. The white column represents the control, the gray columns represent the isolates of Ph. niederhauserii and the striped column represents the isolate of $P p$. vexans.

\section{Discussion}

This study presents the results of a three-year survey of oomycetes associated with root and crown rot of almond trees in Spain. We found a great diversity of oomycete species belonging to the genera Globisporangium, Phytophthora, Phytopythium and Pythium present in root and soil samples, as previously described in almond crops in Iran [12] and 
California $[14,15]$. Phytopythium vexans and $\mathrm{Ph}$. niederhauserii were the most frequent species isolated; thus, its pathogenicity to almond rootstock 'Garnem', widely used in Spain due to its high vigor and high resistance to Meloidogyne spp., chlorosis and drought [37], was investigated. Moreover, most of the oomycetes were isolated from the soil samples with baiting techniques. It is well known that most oomycetes are difficult to isolate from necrotic tissues because they often harbor many secondary pathogens; therefore, performing the baiting of soil samples taken from affected trees is the best approach $[28,38]$.

The high frequency of $P p$. vexans agrees with the results from a study conducted in peach-orchard replanting soil in California by Yang et al. [39], who reported a 65\% prevalence of this species in peach trees, showing a dramatic reduction in plant growth, vigor and yield, with a shortened production life. Phytopythium vexans was considered a saprophytic species, rapidly colonizing dead roots in peach trees, playing an invasive role in respect to secondary decaying rootlets [40]. However, its pathogenicity has recently been confirmed on fruit hosts such as grapevine in South Africa [41], avocado in Spain [42] and apple trees in Morocco [43]. Regarding the inoculation of Pp. vexans on the 'Garnem' rootstock, our results show a high severity of symptoms at the late stage of the pathogenicity test, which corresponded with advanced defoliation, wilting and dieback symptoms, leading to the plant death of some seedlings. On the contrary, the dry weight of the root did not reduce compared with the control. Similar results were obtained by Ivors et al. [44], who indicated that the root rot indices and the maximum fresh weight of Fraser fir plants (Abies fraseri (Pursh) Poir) inoculated with Pp. vexans were not significantly different from the weight of the controls. To our knowledge, there are no previous works that reported the pathogenicity of this species on almonds; thus, our study is the first report of Pp. vexans as an almond pathogen.

The second species with the highest frequency of isolation was Ph. niederhauserii. Previous studies conducted in Spain reported it for the first time to be affecting almond trees in nurseries [20], but our results confirm that this species is currently present in almond orchards in diverse Spanish provinces. Later, this oomycete was found to affect almonds in Turkey [21] and California [15]. Regarding its pathogenicity to 'Garnem' rootstock, the four isolates included in our study caused severe symptoms in the aerial part of the seedlings at the end of the experiment, although only the isolates PAL-74 and PAL-100 significantly reduced the dry weight of the roots compared with the control. Root dry-weight reduction could possibly be the consequence of the reduction in the lateral roots, due to the necrosis caused by Ph. niederhauserii infection. This effect was already described by RodríguezPadrón et al. [42] and Kurbetli et al. [45], when these authors inoculated Ph. niederhauserii to avocado and pomegranate, respectively. Furthermore, both research works evidenced that infection by this species was more virulent than that caused by other Phytophthora species evaluated. Although attacks of Ph. niederhauserii have been reported in other crops, mainly ornamental hosts [22,46,47], its worldwide geographical distribution in almond crops is still limited.

Globisporangium irregulare and G. ultimum var. ultimum presented an isolation frequency of less than 10\%. Mircetich [40] indicated that G. irregulare and G. ultimum var. ultimum were isolated with high frequency in peach orchards, but there was no relationship between the decay of the trees and the frequency of appearance of these species in the roots. For this reason, this author suggested that both species may be saprophytes on the roots of the peach tree. Although the pathogenicity of G. irregulare and G. ultimum var. ultimum was not investigated in our study, it has been previously studied in America. In Chile, Pinto de Torres and Mircetich [11] reported trunk rot at the crown area of almond trees caused by G. ultimum. Later, in Michigan, USA, Smither and Jones [48] isolated G. irregulare from the ground, in sour cherry orchards, with symptoms of discolored and necrotic roots, in which Phytophthora spp. are commonly found. In greenhouse trials, increased root discoloration, necrosis and reductions in root and shoot growth occurred on sour cherry seedlings inoculated with G. irregulare. These authors concluded that, despite causing these symptoms, G. irregulare was not able to kill this host. For this reason, they suggested that 
this species was not the cause of the decline in and death of cherry trees in the evaluated orchards but may contribute to a reduction in the growth of cherry trees planted in heavy soils. Coinciding with our study, Yang et al. [39] reported a low isolation frequency of G. irregulare in replanting soils of peach orchards in California; around $8 \%$ of the isolates of total oomycetes recovered. Regarding the pathogenicity of these species, in California, Schmidt and Browne [49] detected the presence of Pythium sp. associated with Prunus Replant Disease (PRD), a little-known disease caused by a complex of soil microorganisms. These authors carried out pathogenicity tests in the greenhouse, with grafted peach trees on 'Nemaguard' rootstock, inoculating G. irregulare and G. ultimum, among others. In this study, G. irregulare and G. ultimum significantly reduced the fresh weight of the 'Nemaguard' rootstock and caused various levels of necrosis of the root cortex, confirming that these species contribute to the development of PRD.

The isolation frequency of $P y$. dissotocum was also less than $10 \%$. This oomycete has been described mainly as a pathogen of vegetables grown in hydroponic conditions such as lettuce in the USA [50], sweet peppers in Canada [51] and spinach in China [52], but not on fruit crops.

Phytophthora cactorum and Ph. citrophthora were isolated less than $7 \%$. These results match with previous works performed by Wicks and Lee [16] and Browne and Viveros [18], who reported the isolation of these pathogens from almond cankers and soil, without proving their pathogenicity. Later, in Iran, Sahragard and Banihashemi [19] confirmed the pathogenicity of Ph. cactorum in a local almond tree rootstock, which increased mortality rate and decreased root weight. Despite this, the literature is not conclusive in associating specific Phytophthora species with root rot and cankers on the root crown, trunk, or scaffolds, observed in almond trees [15]. Multiple species, such as Ph. cambivora, Ph. cryptogea [17], Ph. citricola [18], Ph. megasperma [23], Ph. plurivora [24] and Ph. chlamydospora [25,26], have been associated with almond crops, but they were not found in our survey.

The remaining oomycete species were found with a very low frequency and were occasionally isolated from a few samples. Most of these species are pathogens of ornamentals, cereals, vegetables and some fruit trees and some have also been described as saprophytes. However, Pp. helicoides has been reported as a pathogen in Prunus in California, causing root rot and roots of stunted seedlings of 'Nemaguard' peach rootstock [14].

Disease severity, AUDPC and root dry weight were useful parameters to evaluate the pathogenicity of $P p$. vexans and $P h$. niederhauserii to almond rootstock 'Garnem'. The application of standard protocols for pathogenicity testing and disease assessment in plants facilitates inter-study comparisons, thus improving accuracy [53]. Moreover, further studies about pathogenicity testing of oomycetes to Prunus rootstocks would improve the understanding of their infections mechanisms and identifying methods to provide durable resistance, which are major research goals for rootstock breeding programs [54,55].

The results of our research study provide new information about the pathogenic oomycete species present in almond crops in Spain, which represent an emerging threat for almond and other Prunus spp. production. They also highlight the importance of carrying out frequent phytosanitary surveys in fruit nurseries and orchards for a better knowledge of potential risks posed by soil borne pathogens, including the pathogenicity evaluation of the species found.

Author Contributions: Conceptualization, F.B., X.M., L.T., J.A. and P.A.-C.; methodology, F.B., X.M., L.T., J.A. and P.A.-C.; software, F.B.; validation, F.B., X.M., L.T., J.A. and P.A.-C.; formal analysis, F.B., J.A. and P.A.-C.; investigation, F.B., X.M., L.T., J.A. and P.A.-C.; resources, J.A. and P.A.-C.; data curation, F.B., J.A. and P.A.-C.; writing-original draft preparation, F.B., J.A. and P.A.-C.; writingreview and editing, F.B., X.M., J.A. and P.A.-C.; visualization, F.B., X.M., L.T., J.A. and P.A.-C.; supervision, F.B., J.A. and P.A.-C.; project administration, J.A. and P.A.-C.; funding acquisition, J.A. and P.A.-C. All authors have read and agreed to the published version of the manuscript.

Funding: This research study was funded by INIA (Instituto Nacional de Investigación y Tecnología Agraria y Alimentaria), Spain, through projects RTA2017-00009-C04-01 and RTA2017-00009-C04-04, 
and matching funds from the ERDF (European Regional Development Fund) and Grant PID2020114648RR-C33 funded by MCIN/AEI/ 10.13039/501100011033.

Institutional Review Board Statement: Not applicable.

Informed Consent Statement: Not applicable.

Data Availability Statement: Not applicable.

Acknowledgments: Francisco Beluzán was supported by Agencia Nacional de Investigación y Desarrollo/Subdirección de Capital Humano/Doctorado Becas Chile en el Extranjero/72200145. Xavier Miarnau was supported by the CERCA Program, Generalitat de Catalunya.

Conflicts of Interest: The authors declare no conflict of interest.

\section{References}

1. Gradziel, T.; Curtis, R.; Socias i Company, R. Production and Growing Regions. In Almonds: Botany, Production and Uses; Socias i Company, R., Gradizel, T., Eds.; CABI: Wallingford, UK, 2017; pp. 70-86.

2. $\quad$ Felipe, A. El Almendro I: El Material Vegetal, 1st ed.; Mira Editores: Zaragoza, Spain, 2000; pp. 1-461.

3. Miarnau, X.; Torguet, L.; Batlle, I.; Alegre, S. El cultivo del almendro en alta densidad. Rev. Frutic. 2016, $49,68-87$.

4. Torguet, L.; Maldonado, M.; Miarnau, X. Importancia y control de las enfermedades en el cultivo del almendro. Agri. Rev. Agropec. Gan. 2019, 1026, 72-77.

5. Rubio-Cabetas, M.; Felipe, A.; Reighard., G. Rootstock Development. In Almonds: Botany, Production and Uses; Rafel Socias i Company, Gradizel, T., Eds.; CABI: Wallingford, UK, 2017; pp. 209-227.

6. Iglesias, I.; Carbó, J. Situació actual, característiques i comportament agronòmic dels portaempelts de presseguer. Dossier Tècnic. 2006, 17, 3-18.

7. Pinochet, J. 'Replantpac' (Rootpac®R), a plum-almond hybrid rootstock for replant situations. HortScience 2010, 45, $299-301$. [CrossRef]

8. Teviotdale, B.; Michailides, T.; Pscheidt, J. Compendium of Nut Crop Diseases in Temperate Zones; American Phytopathological Society: Portland, OR, USA, 2002; pp. 18-429.

9. Pérez-Sierra, A.; Mora-Sala, B.; León-Santana, M.; García-Jiménez, J.; Abad-Campos, P. Enfermedades causadas por Phytophthora en viveros de plantas ornamentales. Bol. Sanid. Veg. Plagas 2012, 38, 143-156.

10. Wang, Y.; Tyler, B.; Wang, Y. Defense and counterdefense during plant-pathogenic oomycete infection. Annu. Rev. Microbiol. 2019, 73, 667-696. [CrossRef]

11. Pinto de Torres, A.; Mircetich, S. Pythium ultimun Trow causante de pudrición del tronco en plántulas de frutales de carozo y en almendros y damascos de dos años. Agric. Téc. 1976, 36, 171-173.

12. Azizi, Z.; Amini, J.; Shaykh-Eslami, M.; Abasi, S. Pathogenicity of some isolates of Pythium and Phytophthora on detached shoots and seedlings of almond. Iran. J. Plant. Pathol. 2013, 49, 33-39.

13. Javadi, N.; Sharifnabi, B. Phytopythium litorale, the Causal Agent of Almond Root and Crown rot in Iran. Proceedings of 22nd Iranian Plant Protection Congress, Karaj, Iran, 27-30 August 2016; College of Agriculture and Natural Resources: Karaj, Iran, 2016; pp. 27-30.

14. Browne, G.; Ott, N.; Fichtner, E. First Report of Phytopythium helicoides causing root rot on peach rootstock in California. Plant. Dis. 2019, 103, 2968. [CrossRef]

15. Browne, G.; Schmidt, L.; Brar, G. First report of Phytophthora niederhauserii causing crown rot of almond (Prunus dulcis) in California. Plant. Dis. 2015, 99, 1863. [CrossRef]

16. Wicks, T.; Lee, T. Phytophthora crown rot of almond trees. Aust. J. Agric. Res. 1986, 37, 277-287. [CrossRef]

17. Wicks, T. Susceptibility of almond and cherry rootstocks and scions to Phytophthora species. Aust. J. Exp. Agric. 1989, 29, 103-109. [CrossRef]

18. Browne, G.; Viveros, M. Diverse symptoms and tree losses caused by Phytophthora spp. in California almonds. Acta Hortic. 1997, 470, 570-575. [CrossRef]

19. Sahragard, N.; Banihashemi, Z. Evaluation of resistance of some almond genotypes and cultivars to Phytophthora cactorum. Iran. J. Plant. Pathol. 2006, 42, 97-99.

20. Pérez-Sierra, A.; León, M.; Álvarez, L.; Alaniz, S.; Berbegal, M.; García-Jiménez, J.; Abad-Campos, P. Outbreak of a new Phytophthora sp. associated with severe decline of almond trees in eastern Spain. Plant. Dis. 2010, 94, 534-541. [CrossRef]

21. Kurbetli, I.; Değirmenci, K. First report of Phytophthora taxon niederhauserii causing decline of almond in Turkey. New Dis. Rep. 2011, 23, 14. [CrossRef]

22. Abad, G.; Abad, J.; Cacciola, S.; Pane, A.; Faedda, R.; Moralejo, E.; Pérez-Sierra, A.; Abad-Campos, P.; Álvarez-Bernaola, L.; Bakonyi, J.; et al. Phytophthora niederhauserii sp. nov., a polyphagous species associated with ornamentals, fruit trees and native plants in 13 countries. Mycologia 2014, 106, 431-447. [CrossRef]

23. Kurbetli, İ.; Y1lmaz, A. Almond decline caused by Phytophthora megasperma in southeastern Anatolian region of Turkey. J. Turk. Phytopathol. 2016, 45, 13-20. 
24. Çiftçi, O.; Türkölmez, Ş.; Derviş, S.; Serçe, Ç. First report of canker and root rot of almond caused by Phytophthora plurivora in Turkey. Plant. Dis. 2016, 100, 1507. [CrossRef]

25. Türkölmez, Ş.; Derviş, S.; Çiftçi, O.; Ulubaş Serçe, Ç. First report of Phytophthora chlamydospora causing root and crown rot on almond (Prunus dulcis) trees in Turkey. Plant. Dis. 2016, 100, 1796. [CrossRef]

26. Browne, G.; Ott, N.; Forbes, H.; Yaghmour, M.; Milliron, L. First Report of Phytophthora chlamydospora causing crown and root rot on almond in California. Plant. Dis. 2020, 104, 2033. [CrossRef]

27. Jeffers, S.; Martin, S. Comparison of two media selective for Phytophthora and Pythium species. Plant. Dis. 1986, 70, 1038-1043. [CrossRef]

28. Erwin, D.; Ribeiro, O. Phytophthora Disease Worldwide; American Phytopathology Society Press: Saint Paul, MN, USA, 1996; pp. 1-562.

29. Linderman, R.; Zeitoun, F. Phytophthora cinnamomi causing root rot and wilt of nursery-grown native western azalea and salal Plant. Dis. Report. 1977, 61, 1045-1048.

30. Collado-Romero, M.; Mercado-Blanco, J.; Olivares-García, C.; Valverde-Corredor, A.; Jiménez-Díaz, R. Molecular variability within and among Verticillium dahliae vegetative compatibility groups determined by fluorescent amplified fragment length polymorphism and polymerase chain reaction markers. Phytopathology 2006, 96, 485-495. [CrossRef]

31. Cooke, D.; Drenth, A.; Duncan, J.; Wagels, G.; Brasier, C. A molecular phylogeny of Phytophthora and related oomycetes. Fungal Genet. Biol. 2000, 30, 17-32. [CrossRef]

32. White, T.; Bruns, T.; Lee, S.; Taylor, J. Amplification and direct sequencing of fungi ribosomal RNA genes for phylogenetics. In PCR Protocols. A Guide to Methods and Applications; Innis, M., Gelfand, D., Sninsky, J., White, T., Eds.; Academic Press: Millbrae, CA, USA, 1990; pp. 315-322.

33. Jung, T.; Blaschke, H.; Neumann, P. Isolation, identification and pathogenicity of Phytophthora species from declining oak stands. Eur. J. For. Pathol. 1996, 26, 253-272. [CrossRef]

34. Pérez-Sierra, A.; López-García, C.; León, M.; García-Jiménez, J.; Abad-Campos, P.; Jung, T. Previously unrecorded low-temperature Phytophthora species associated with Quercus decline in a Mediterranean forest in eastern Spain. For. Pathol. 2013, 43, 331-339. [CrossRef]

35. Jönsson, U.; Jung, T.; Rosengren, U.; Nihlgård, B.; Sonesson, K. Pathogenicity of Swedish isolates of Phytophthora quercina to Quercus robur in two different soils. New Phytol. 2003, 158, 355-364. [CrossRef]

36. Campbell, C.; Madden, L. Introduction to plant disease epidemiology, 1st ed; John Wiley \& Sons: New York, NY, USA, 1990; pp. 192-194.

37. Bielsa, B.; Rubio-Cabetas, M. La elección del patrón en la almendricultura moderna. Rev. Frut. 2018, 65, 92-113.

38. Drenth, A.; Sendall, B. Practical Guide to Detection and Identification of Phytophthora; CRC for Tropical Plant Protection: Brisbane, Australia, 2001; pp. 1-41.

39. Yang, J.; Ruegger, P.; McKenry, M.; Becker, J.; Borneman, J. Correlations between root-associated microorganisms and peach replant disease symptoms in a California Soil. PLoS ONE 2012, 7, e46420. [CrossRef]

40. Mircetich, S. The role of Pythium in feeder roots of diseased and symptomless peach trees. Phytopathology 1971, 61, 357-360. [CrossRef]

41. Langenhoven, S.; Halleen, F.; Spies, C.; Stempien, E.; Mostert, L. Detection and quantification of black foot and crown and root rot pathogens in grapevine nursery soils in the Western Cape of South Africa. Phytopathol. Mediter. 2018, 57, 519-537. [CrossRef]

42. Rodríguez-Padrón, C.; Siverio, F.; Pérez-Sierra, A.; Rodríguez, A. Isolation and pathogenicity of Phytophthora species and Phytopythium vexans recovered from avocado orchards in the Canary Islands, including Phytophthora niederhauserii as a new pathogen of avocado. Phytopathol. Mediterr. 2018, 57, 89-106. [CrossRef]

43. Jabiri, S.; Lahlali, R.; Bahra, C.; Amraoui, M.; Tahiri, A.; Amiri, S. First report of Phytopythium vexans associated with dieback disease of apple trees in Morocco. J. Plant. Pathol. 2020, 102, 1319. [CrossRef]

44. Ivors, K.; Abad, Z.; Benson, D. Evaluating the pathogenicity of Pythium vexans isolates from Fraser fir in North Carolina. Plant. Health Prog. 2008, 9, 8. [CrossRef]

45. Kurbetli, İ.; Karaca, G.; Aydoğdu, M.; Sülü, G. Phytophthora species causing root and collar rot of pomegranate in Turkey. Eur. J. Plant. Pathol. 2020, 157, 485-496. [CrossRef]

46. Moralejo, E.; Pérez-Sierra, A.; Álvarez, L.; Belbahri, L.; Lefort, F.; Descals, E. Multiple alien Phytophthora taxa discovered on diseased ornamental plants in Spain. Plant. Pathol. 2009, 58, 100-110. [CrossRef]

47. Prigigallo, M.; Mosca, S.; Cacciola, S.; Cooke, D.; Schena, L. Molecular analysis of Phytophthora diversity in nursery-grown ornamental and fruit plants. Plant. Pathol. 2015, 64, 1308-1319. [CrossRef]

48. Smither, M.; Jones, A. Pythium species associated with sour cherry and the effect of $P$. irregulare on the growth of mahaleb cherry. Can. J. Plant. Pathol. 1989, 11, 1-8. [CrossRef]

49. Schmidt, L.; Browne, G. Characterization of Pythium species associated with Prunus replant disease. In Phytopathology; The American Phytopathological Society: Saint Paul, MN, USA, 2013; Volume 103, p. 128.

50. McGehee, C.; Raudales, R.; Elmer, W. First report of Pythium dissotocum causing Pythium root rot on hydroponically grown lettuce in Connecticut. Plant. Dis. 2018, 102, 2043. [CrossRef]

51. Owen-Going, N.; Sutton, J.; Grodzinski, B. Relationships of Pythium isolates and sweet pepper plants in single-plant hydroponic units. Can. J. Plant. Pathol. 2003, 25, 155-167. [CrossRef] 
52. Huo, C.; Cao, J.; Wu, K.; Chen, Y.; Zhao, Z. First Report of Pythium dissotocum causing root rot on hydroponically grown spinach in China. Plant. Dis. 2020, 104, 3084. [CrossRef]

53. Bhunjun, C.; Phillips, A.; Jayawardena, R.; Promputtha, I.; Hyde, K. Importance of molecular data to identify fungal plant pathogens and guidelines for pathogenicity testing based on Koch's Postulates. Pathogens 2021, 10, 1096. [CrossRef]

54. Fawke, S.; Doumane, M.; Schornack, S. Oomycete interactions with plants: Infection strategies and resistance principles. Microbiol. Mol. Biol. Rev. 2015, 79, 263-280. [CrossRef]

55. El Hadrami, A.; El-Bebany, A.; Yao, Z.; Adam, L.; El Hadrami, I.; Daayf, F. Plants versus fungi and oomycetes: Pathogenesis, defense and counter-defense in the proteomics era. Int. J. Mol. Sci. 2012, 13, 7237-7259. [CrossRef] 